\title{
PENGARUH PENAMBAHAN RENDENG KEDELAI DALAM RANSUM TERHADAP PERTAMBAHAN BOBOT BADAN KAMBING PERANAKAN ETAWA JANTAN
}

\author{
Lukman Hakim $^{1}$, Arif Aria Hertanto ${ }^{2}$, Edy Susanto ${ }^{3}$ \\ ${ }^{1}$ Program Studi Peternakan Fakultas Peternakan Universitas Islam Lamongan \\ ${ }^{2}$ dan 3 Fakultas Peternakan - Universitas Islam Lamongan \\ Jl. Veteran No. 53 \\ e-mail: $\underline{\operatorname{lh} 7079580 @ g m a i l . c o m}$
}

\begin{abstract}
Abstrak
Penelitian ini dilaksanakan pada tanggal 01 April sampai 30 Mei 2017 di kandang ternak milik bapak Karno Dusun Banyuwet Desa Kedukbembem Kecamatan Mantup Kabupaten Lamongan. Tujuan dari penelitian ini adalah untuk mengetahui pengaruh penambahan rendeng kedelai dalam ransum terhadap pertambahan bobot badan kambing peranakan Etawa jantan. Kegunaan dari penelitian ini diharapkan dapat digunakan sebagai bahan pengganti konsentrat dalam ransum. Materi yang digunakan dalam penelitian ini adalah 9 ekor kambing peranakan Etawa jantan dengan bobot awal 19 - $30 \mathrm{~kg} / \mathrm{ekor}$, Konsentrat, rendeng kedelai, rumput lapang dan air. Metode yang digunakan dalam penelitian ini adalah Rancangan Acak Lengkap yang terdiri dari 3 perlakuan dan 3 ulangan. Adapun 3 perlakuan tersebut terdiri dari $P_{0}$ : konsentrat 30\% + Rendeng Kedelai $0 \%+R L 70 \%, P_{1}:$ konsentrat $20 \%+$ Rendeng Kedelai $10 \%+R L$ 70\%, $P_{2}$ : konsentrat 10\% + Rendeng Kedelai $20 \%+R L$ 70\%, Setiap ulangan di isi 1 ekor kambing. Variable yang diamati dalam penelitian ini adalah pertambahan bobot badan kambing peranakan Etawa jantan. Data dianalisis dengan metode statistik Rancangan Acak Lengkap. Jika hasil memerlihatkan pengaruh nyata maka akan dilakukan uji lanjut dengan mengunakan (Uji Jarak Berganda Duncan) Penimbangan bobot badan dilakukan setiap satu minggu sekali. Hasil penelitian menunjukkan bahwa pengaruh penambahan rendeng kedelai dalam ransum kambing peranakan Etawa jantan. tidak memberikan pengaruh nyata $(P>0,05)$ terhadap pertambahan bobot badan kambing peranakan Etawa jantan. Akan tetapi pertambahan bobot badan kambing peranakan etawa $\left(P_{1}\right.$ dan $\left.P_{2}\right)$ cenderung lebih tinggi dibandingkan kontrol $\left(P_{0}\right)$.
\end{abstract}

Kata kunci : Kambing Peranakan Etawa, Rendeng Kedelai, pertambahan berat badan.

\section{PENDAHULUAN}

Kebutuhan gizi bagi rakyat Indonesia semakin meningkat seiring dengan meningkatnya kesadaran akan pentingnya protein hewani untuk kesehatan dan untuk mendukung ketercukupan nutrisi yang dibutuhkan oleh tubuh. Sumber protein dapat diperoleh dari hasil ternak yaitu berupa daging, telur maupun susu. Kambing merupakan salah satu jenis ternak ruminansia penghasil daging yang cukup potensial. Kambing dapat memanfaatkan bahan alami dan hasil ikutan industri yang tidak dikonsumsi oleh manusia sebagai bahan pakan. Rendeng kedelai /jerami kedelai (Glycine maxL. Merr.) merupakan salah satu limbah tanaman pangan di Kabupaten Lamongan tepatnya di Kecamatan Mantup cukup potensial dan sampai saat ini belum dimanfaatkan secara optimal. Luas areal panen tanaman kedelai di daerah ini pada tahun 2015 menghasilkan 4,5 Ribu Ton dari tahun sebelumnya (BPS Lamongan 2015). Hal ini akan berimplikasi terhadap peningkatan produksi limbah jerami kedelai yang dapat 
dimanfaatkan sebagai pakan ternak. Bagaimana pengaruh penambahan Rendeng kedelai dalam ransum terhadap Pertambahan Bobot Badan kambing Peranakan Etawa jantan. Tujuan penelitian ini adalah untuk mengetahui pengaruh penambahan Rendeng kedelai dalam ransum terhadap Pertambahan Bobot Badan kambing Peranakan Etawa jantan. $\mathrm{H}_{0}=$ Tidak terdapat pengaruh penambahan Rendeng kedelai dalam ransum terhadap Pertambahan Bobot Baban kambing Peranakan Etawa jantan. $\mathrm{H}_{1}=$ pengaruh penambahan Rendeng kedelai dalam ransum terhadap Pertambahan Bobot Badan kambing Peranakan Etawa jantan. Kambing merupakan hewan domestikasi tertua yang telah bersosialisasi dengan manusia lebih dari 1000 tahun. Kambing tergolong pemamah biak, berkuku genap dan memiliki sepasang tanduk yang melengkung. Kambing merupakan hewan pegunungan hidup dilereng-lereng yang curam yang memiliki sifat adaptasi yang cukup baik terhadap perubahan musim (Sarwono, (2009) dalam Susanto, (2014)).

Mulyono dan Sarwono (2010) dalam Susanto (2014) menyatakan kambing peranakan Etawa (PE) merupakan hasil persilangan antara kambing Etawa dari India dengan kambing Kacang yang penampilannya mirip Etawa tetapi lebih kecil. Kambing peranakan Etawa (PE) memiliki dua kegunaan, yaitu sebagai penghasil susu (perah) dan kambing potong. Jerami kedelai (Glycine max L. Merr.) merupakan salah satu limbah tanaman pangan di Kabuaten Keerom yang cukup potensial dan sampai saat ini belum dimanfaatkan secara optimal. Luas areal panen tanaman kedelai di daerah ini pada tahun 2012 meningkat 229,5\% dari tahun sebelumnya. Hal ini akan berimplikasi terhadap peningkatan produksi limbah jerami kedelai yang dapat dimanfaatkan sebagai pakan. Produksi limbah tanaman pangan di suatu wilayah dapat diperkirakan berdasarkan luas areal panennya (Jayasuriya 2002 dalam Prasetyo, (2006)).

Kandungan gizi jerami kedelai adalah 97,08\% bahan kering; 5,69\% abu; 0,23\% lemak kasar; $59,20 \%$ serat kasar; 4,22\% protein kasar; $30,66 \%$ bahan ekstrak tanpa nitrogen dan 3,259
$\mathrm{Mkal} / \mathrm{kg}$ gross energi. Nilai kecernaan bahan kering jerami kedelai adalah 30\% (ASHARI dkk., (1996) dalam Prasetyo, (2006)).

\section{METODE}

Penelitian ini dilakukan dengan metode Rancangan Acak Lengkap (RAL) terdiri dari 3 perlakuan. Setiap perlakuan menggunakan 3 ulangan dan setiap ulangan menggunakan 1 ekor kambing PE. Metode yang digunakan dalam penelitian ini adalah eksperimen. Susunan perlakuan sebagai berikut :

P0 : Konsentrat $30 \%$ + Rendeng Kedelai $0 \%$ + $\mathrm{RL} 70 \%$,

P1 : Konsentrat $20 \%+$ Rendeng Kedelai $10 \%$ $+\mathrm{RL} 70 \%$,

P2 : Konsentrat $10 \%$ + Rendeng Kedelai $20 \%$ $+\mathrm{RL} 70 \%$

Ternak kambing diberi pakan $2 \mathrm{X}$ sehari, yaitu pada pagi hari dan sore hari (09:00) pagi dan sore hari (15:00). Pakan konsentrat di berikan terlebih dahulu sebelum pemberian pakan rumput lapang. Pemberian air minum di berikan secara ( $A d$-libitum). Penimbangan bobot badan di lakukan setiap 1 minggu sekali.

\section{HASIL DAN PEMBAHASAN}

Data penelitian pertambahan bobot badan kambing PE (Peranakan Etawa) dan hasil uji statistiknya dapat dilihat pada Tabel 4.1 berikut ini.

Tabel 4.1 Data Pertambahan Bobot Badan Kambing PE (Peranakan Etawa) (g/ekor/hari).

\begin{tabular}{crrrrr}
\hline \multirow{2}{*}{ Perlakuan } & \multicolumn{3}{c}{ Ulangan } & \multirow{2}{*}{ Total } & \multirow{2}{*}{ Rataan } \\
\cline { 2 - 4 } & \multicolumn{1}{c}{$\mathbf{1}$} & \multicolumn{1}{c}{$\mathbf{3}$} & & \\
\hline $\mathbf{P}_{\mathbf{0}}$ & 95,2 & 83,8 & 92,3 & 271,3 & 90,43 \\
$\mathbf{P}_{\mathbf{1}}$ & 89,2 & 96,9 & 94,0 & 280,1 & 93,36 \\
$\mathbf{P}_{\mathbf{2}}$ & 91,1 & 110,4 & 93,8 & 295,3 & 98,43 \\
\hline Total & 275,5 & 291,1 & 280,1 & 846,7 & 282,22 \\
\hline
\end{tabular}

Sumber : Data diolah (2017).

Keterangan : Superscript yang sama pada kolom yang sama menunjukkan tidak berbeda nyata $(P>0,5)$. 
Tabel 4.2 ANOVA Pertambahan Bobot

Badan Kambing PE

(Peranakan Etawa)

\begin{tabular}{|l|c|c|c|c|c|c|}
\hline \multicolumn{1}{|c|}{ SK } & Db & JK & \multirow{2}{*}{ KT } & \multirow{2}{*}{$\mathbf{F}_{\text {hitung }}$} & \multicolumn{2}{|c|}{$\mathbf{F}_{\text {tabel }}$} \\
\cline { 1 - 1 } & & & & & $\mathbf{5 \%}$ & $\mathbf{1} \%$ \\
\hline Perlakuan & 2 & 98,27 & 49,13 & & & \\
\hline Galat & 6 & 318,91 & \multirow{2}{*}{0,924} & 5,14 & 4,76 \\
\hline Total & 8 & 417,18 & 53,15 & & & \\
\hline
\end{tabular}

Sumber : Data diolah (2017).

Keterangan : Superscript yang sama pada kolom yang sama menunjukkan tidak berbeda nyata $(P>0,5)$.

Berdasarkan hasil uji statistik dan data pada Tabel 4.1 menunjukkan bahwa perbedaan pertambahan bobot badan kambing yang diberi pakan $\mathrm{P}_{0}$ (konsentrat $30 \%$ dan rumput lapang
$70 \%$ tanpa penambahan rendeng kedelai), $P_{1}$ (konsentrat $20 \%$ + rumput lapang $70 \%$ + rendeng kedelai 10\%), $\mathrm{P}_{2}$ ((konsentrat 10\%+ rumput lapang $70 \%$ + rendeng kedelai $20 \%$ ) tidak berbeda nyata $(P>0,05)$ pada pertambahan bobot badan. Hal ini dapat terlihat pada $\mathrm{P}_{0}$ bobot badan Kambing PE (Peranakan Etawa) meningkat sebanyak $90,43 \mathrm{~g}$ dan $\mathrm{P}_{1}$ bobot badan kambing PE (Peranakan Etawa) meningkat sebanyak 93,36 g. Pada $P_{2}$ mengalami peningkatan sebanyak 98,43 g. Rendeng kedelai tidak memberikan perbeedaan pengaruh yang nyata dikarenakan kandungan serat kasar yang cukup tinggi, hal ini diketahui dengan hasil uji laboratorium, seperti pada Tabel 4.3 berikut ini :

Tabel 4.3 Hasil Analisis Proksimat Laboratorium UNAIR (2017)

\begin{tabular}{ccccccccc}
\hline Kode & Bahan & Abu & $\begin{array}{c}\text { Protein } \\
\text { Kasar }\end{array}$ & $\begin{array}{c}\text { Lemak } \\
\text { Kasar }\end{array}$ & $\begin{array}{c}\text { Serat } \\
\text { Kasar }\end{array}$ & Ca & BETN & $\begin{array}{c}\text { ME } \\
\text { (Kcal/kg) }\end{array}$ \\
\hline $\begin{array}{c}\text { Rendeng } \\
\text { kedele }\end{array}$ & 91,1937 & 6,6974 & 7,2248 & 5,1471 & 20,406 & 0,3391 & 51,664 & 2560,5 \\
\hline
\end{tabular}

Sumber : Hasil Analisis Proksimat Laboratorium UNAIR (2017)

\section{Konsumsi Pakan}

Hasil pengamatan menunjukkan bahwa pada $\mathrm{P}_{0}$ mengkonsumsi protein kasar terendah karena tidak diberikan pakan tambahan rendeng kedelei, hanya mengkonsumsi rumput lapang . Pemberian pakan rendeng kedelei pada kambing, $P_{1}=10 \%$ dan $P_{2}=20 \%$ dapat dihabiskan. Hal ini menandakan bahwa porsi tersebut dapat memenuhi kekurangan kebutuhan protein kasar dari rerumputan yang dikonsumsi kambing. Berdasarkan penelitian yang telah dilakukan didapat data sebagaimana dalam Tabel 4.4 berikut ini:

Tabel 4.4 Data Konsumsi Pakan Kambing Peranakan Etawa (PE) (g/ekor/hari).

\begin{tabular}{|c|c|c|c|c|c|}
\hline \multirow[t]{2}{*}{ Perlakuan } & \multicolumn{3}{|c|}{$\begin{array}{c}\text { Konsumsi pakan } \\
\text { (gram) } \\
\text { Ulangan }\end{array}$} & \multirow[t]{2}{*}{ Total } & \multirow[t]{2}{*}{ Rataan } \\
\hline & 1 & 2 & 3 & & \\
\hline$P_{0}$ & 1728,166 & $\begin{array}{c}1832 \\
333\end{array}$ & $\begin{array}{c}1740 \\
333\end{array}$ & $\begin{array}{c}5300 \\
, 832\end{array}$ & $\begin{array}{c}1766,94 \\
4\end{array}$ \\
\hline $\mathbf{P}_{1}$ & 1908,333 & $\begin{array}{c}1881 \\
000\end{array}$ & $\begin{array}{c}1995 \\
500\end{array}$ & $\begin{array}{c}5784 \\
, 833\end{array}$ & $\begin{array}{c}1928,27 \\
7\end{array}$ \\
\hline $\mathbf{P}_{2}$ & 2160,166 & $\begin{array}{c}1852 \\
000\end{array}$ & $\begin{array}{c}2319 \\
833\end{array}$ & $\begin{array}{r}6331 \\
, 999\end{array}$ & $\begin{array}{c}2110,66 \\
6\end{array}$ \\
\hline Total & 5796,665 & $\begin{array}{c}5565 \\
333\end{array}$ & $\begin{array}{c}6055 \\
666\end{array}$ & $\begin{array}{c}1741 \\
7,66 \\
4\end{array}$ & $\begin{array}{c}5805,88 \\
7\end{array}$ \\
\hline
\end{tabular}

Sumber : Data diolah (2017).

Keterangan : Superscript yang sama pada kolom yang sama menunjukkan tidak berbeda nyata $(P>0,5)$.

Berdasarkan Tabel 4.4 dan analisis sidik ragam (lampiran 6 / diketahui bahwa tidak terdapat perbedaan nyata $(P>0.05)$ pengaruh rendeng kedelai terhadap konsumsi kambing $P E$ jantan. 
Tabel 4.5 ANOVA Konsumsi Pakan

\begin{tabular}{|c|c|c|c|c|c|c|}
\hline \multirow{2}{*}{ SK } & \multirow{2}{*}{ Db } & JK & KT & $\boldsymbol{F}_{\text {hitung }}$ & \multicolumn{2}{|c|}{$\mathbf{F}_{\text {tabel }}$} \\
\cline { 1 - 4 } & & & & $\mathbf{5 \%}$ & $\mathbf{1 \%}$ \\
\hline Perlakuan & 2 & 177439,219 & 88719,6095 & \multirow{2}{*}{4,19} & & \\
\hline Galat & 6 & 126748,594 & 21124,7656 & & & 4,76 \\
\hline Total & 8 & 304187,813 & & & \\
\hline
\end{tabular}

Sumber : Data diolah (2017).

Keterangan : Superscript yang sama pada kolom yang sama menunjukkan tidak berbeda nyata $(P>0,5)$.

Pada penelitian ini konsumsi pakan kambing peranakan etawa total selama 6 minggu adalah sebesar 17417,664 g. Konsumsi Pakan dapat dipengaruhi oleh berbagai faktor, salah satu faktor utama menurut Hernandez dkk., (2004) dalam Lase (2016) adalah kualitas pakan termasuk kandungan gizi yang terdapat didalam pakan tersebut.

\section{Konversi Pakan}

Data penelitian konversi pakan kambing PE (Peranakan Etawa) dan hasil uji statistiknya dapat dilihat pada Tabel 4.6 berikut ini.

Tabel 4.6 Data Konversi Pakan Kambing PE (Peranakan Etawa) (g/ekor/hari ).

\begin{tabular}{|c|c|c|c|c|c|}
\hline \multirow{2}{*}{ Perlakuan } & \multicolumn{3}{|c|}{ Ulangan } & \multirow{2}{*}{ Total } & \multirow{2}{*}{ Rata } \\
\hline & 1 & 2 & 3 & & \\
\hline $\mathbf{P}_{0}$ & 18,28 & 22,31 & 19,38 & 59,97 & 19,99 \\
\hline$P_{1}$ & 26,10 & 19,44 & 21,35 & 66,89 & 22,29 \\
\hline $\mathbf{P}_{2}$ & 23,80 & 16,91 & 25,26 & 65,97 & 21,99 \\
\hline Total & 68,18 & 58,66 & 65,99 & $\begin{array}{r}192,8 \\
3\end{array}$ & 64,27 \\
\hline
\end{tabular}

Sumber : Data diolah (2017).

Keterangan : Superscript yang sama pada kolom yang sama menunjukkan tidak berbeda nyata $(P>0,5)$.

Berdasarkan hasil perhitungan sidik ragam, perlakuan yang berbeda pada rendeng kedelai tidak berpengaruh nyata $(P>0,05)$ terhadap konversi pakan.

Tabel 4.7 ANOVA Koversi Pakan

\begin{tabular}{|l|l|l|l|l|l|l|}
\hline \multicolumn{1}{|c|}{ SK } & Db & JK & KT & initung & \multicolumn{2}{|c|}{$\mathbf{F}_{\text {tabel }}$} \\
\cline { 1 - 3 } & & & & & & \\
\hline Perlakuan & 2 & 9,41 & 4,70 & & & \\
\hline Galat & 6 & 71,98 & \multirow{2}{*}{1,99} & 3919 & 5,14 & 4,76 \\
\hline Total & 8 & 81,39 & & & & \\
\hline
\end{tabular}

Sumber : Data diolah (2017).
Keterangan : Superscript yang sama pada kolom yang sama menunjukkan tidak berbeda nyata $(P>0,5)$.

Tabel 4.6. menunjukkan bahwa perlakuan $\mathrm{P}_{1}$, kambing peranakan etawa jantan dengan rataan nilai konversi pakan tertinggi sebesar 22,29 g memiliki pertambahan bobot badan $(280,1 \mathrm{~g})$ sedangkan kambing peranakan etawa jantan dengan nilai konversi pakan terendah sebesar 19,99 g mempunyai pertambahan bobot badan $(271,3 \mathrm{~g})$. Bila dibandingkan konversi pakan standar NRC (2006) menurut Anggorodi (1979), dalam Teresia (2016) yang menyatakan bahwa konversi pakan yang disarankan adalah 3.00 artinya pakan yang digunakan dalam penelitian belum efisien. Maka rataan konversi pakan pada penelitian ini terlalu tinggi, hal ini dikarenakan serat kasar yang tinggi pada pakan yang digunakan pada penelitian dan Menurut Yunita (2008) dalam Sobri (2012), hal ini disebabkan oleh perbedaan iklim di Indonesia yang beriklim tropis dengan standar NRC yang beriklim subtropis merupakan salah satu perbedaan standar nilai konversi pakan, kebutuhan nutrisi di daerah tropis cenderung lebih tinggi dibandingkan daerah subtropis. Bahwa konversi pakan merupakan indikator teknis yang dapat menggambarkan tingkat efisiensi pengunaan pakan, semakin rendah angkah konversi pakan berati semakin baik karena pakan yang di gunakan akan semakin sedikit yang akan menghemat biaya. Konversi pakan yang berbeda dari NRC (2006) sejalan pula dengan konsumsi ransum anak kambing. Seperti yang di konversi pakan dapat digunakan untuk mengetahui efisiensi produksi karena erat kaitannya dengan biaya produksi, semakin rendah nilai konversi pakan maka efisiensi penggunaan pakan makin tinggi. Juarini dkk., (1995) dalam Alwi (2015) menyatakan bahwa semakin tinggi nilai konversi pakan berarti pakan yang digunakan untuk menaikkan bobot badan persatuan berat semakin banyak atau efisiensi pakan rendah. Perry dkk., (2005) dalam Alwi 
(2015) menambahkan bahwa konversi pakan merupakan jumlah pakan yang dikonsumsi untuk mendapatkan kenaikan satu satuan bobot hidup. Kemudian dikatakan bahwa tingginya konversi pakan dapat terkait dengan kandungan serat kasar pakan. Serat kasar yang tinggi dalam pakan akan menyebabkan daya cerna menjadi kecil, sehingga konversi pakan merupakan integrasi dari daya cerna (Anggorodi, (1994) dalam Alwi (2015)).

\section{PENUTUP}

\section{Kesimpulan}

Berdasarkan hasil penelitian dapat disimpulkan bahwa Penambahan rendeng kedelai pada pakan tidak memberikan pengaruh yang nyata $(P<0,05)$ terhadap pertambahan berat badan kambing Peranakan Etawa (PE). Akan tetapi pertambahan bobot badan pada kambing Peranakan Etawa (PE) yang mengkonsumsi rendeng kedelai lebih tinggi dari pada kontrol.

\section{Saran}

Saran yang dapat diberikan dalam penambahan rendeng kedelei pada pakan untuk pertambahan berat badan kambing Peranakan Etawa (PE) adalah :

Perlu adanya penelitian dengan diberikan rendeng kedelei yang lebih dari $20 \%$ agar didapatkan berat badan yang lebih tinggi.

\section{DAFTAR PUSTAKA}

Alwi, Arfan. 2015. Pertambahan Bobot Badan dan Konversi Pakan Ternak Kambing Peranakan Etawa yang Diberi Pakan Silase Jerami Padi dan Daun Gamal (Gliricidia sepium). Skripsi. Fakultas Peternakan, Universitas Hasanuddin. Makassar.

Fahrul, Ilahm. 2008. Karakteristik Pertumbuahn Pra dsn Pasca Sapih Domba Lokal di Unit Pendidikan dan Penelitian Peternakan Jonggol Institute Pertanian Bogor (UP3J-IPB). Skripsi. Sekolah Pasca Sarjana, Institute Pertanian Bogor. Bogor.
Fathoni. 2005. Pengaruh Bobot Badan Awal Terhadap Konsumsi Air Dan Pertambahan Bobot Badan Pada Kambing Peranakan Ettawa (PE) Jantan Didesa Kemantren Kecamatan Paciran Kabupaten Lamongan. Skripsi. Fakultas Peternakan, Universitas Islam Lamongan. Lamongan.

Ilyas, Suryanti. 2016. Komposisi Kimia Air Ssusu Ternak Kambing Peranakan Etawa yang Mendapat Suplemen Multi Nutrisi dengan Ransum Basal Campuran Gamal dan Lamtoro. Skripsi. Fakultas Peternakan, Universitas Hasanuddin. Makassar.

Indah, Brylian. 2009. Kajian Kualitas Ransum Kambing Peranakan Ettawa di Balai Pembibitan dan Budidaya Ternak Ruminansia Kendal. Skrihsi. Fakultas Peternakan, Universitas Diponegoro. Semarang.

Lase, Henry. 2016. Performa Pertumbuhan Puyuh (Cortunix cortunix Japanica) Petelur Betina Silangan Warna Bulu Coklat dan Hitam Di Pusat Pembibitan Puyuh Universitas padjajaran. Fakultas Peternakan, Universitas Padjajaran. Bandung.

Nurmiati. 2014. Pengaruh Jenis Kelamin Teradap Pertumbuan Kambing Kacang yang Dipeliahra Secara Intensif. Skripsi. Jurusan Produksi Ternak Fakultas Peternakan, Universitas Hasanuddin. Makassar.

Prasetyo. 2006. Produksi dan Kualitas Llimbah Pertanian Sebagai Pakan Subtitusi Ternak Ruminansi Kecil Di Kabupaten Brebes. Seminar Nasional Teknologi Peternakan dan Veteriner 2006

Simarmata, Teresia. 2016. Pemberian Pakan Komplit Tinggi Energi Dan Protein Pada Kambing Peranakan Etawa Fase Penyapihan. Fakultas Peternakan Institut Pertanian Bogor. Bogor. 
Sobri. 2012.Peforma Domba Ekor Tipis (Ovis aries) Jantan Yang Digemukkan Dengan Pemberian Biskuit Daun Jagung dan Rumput Lapangan. Fakultas Peternakan. Skripsi. Institut Pertanian Bogor. Bogor.

Sulastri, Siti. 2008. Pengaru Penggunaan Ampas Tempe dalam Ransum Terhadap Kecernaan Nutrien Domba Lokal Jantan. Skripsi. Fakultas Pertanian, Universitas Sebelas Maret. Surakarta.
Susanto, Naris. 2014. Korelasi Ukuran-Ukuran Tubuh dengan Pertambahan Berat Badan pada Kambing Peranakan Etawa (PE) Di Kota Pekanbaru. Skripsi thesis, Universitas Islam Negeri Sultan Sarif Kasim Riau.

Wahyono, Tegu. 2013. Penampilan Produksi Kambing Kacang Jantan yang Diberi Pakan Siap Saji (PSS) Berbasis Silase Tanaman Jagung. Skripsi. Fakultas Pertanian, Institut Pertanian Bogor. Bogor. 